\title{
The impact of capital structure on the performance of microfinance institutions
}

\author{
Ammar Yaser Almansour ${ }^{a}$, Najed Alrawashdeh ${ }^{b^{*}}$ and Bashar Yaser Almansour ${ }^{c}$
}

${ }^{a}$ Amman Arab University, Jordan

${ }^{b}$ Applied Science Private University, Jordan

cSkyline University College, Sharjah, United Arab Emirates

\section{H R O N I C L E}

\begin{tabular}{l}
\hline Article history: \\
Received: September 82019 \\
Received in revised format: Sep- \\
tember 22 2019 \\
Accepted: October 6, 2019 \\
Available online: \\
October 6, 2019 \\
\hline Keywords: \\
Microfinance \\
Business performance \\
Small enterprises
\end{tabular}

\begin{abstract}
In this paper, the microfinance services are evaluated in the context of small-scale businesses in Jordan. The aim of this study is to emphasize on the importance of factors related to micro-finance as it helps in enhancing the firm's performance. This study utilizes a quantitative approach to conduct a research on approximately 308 small-scale businesses. The study employs a method of confirmatory component analysis (CFA) held by applied Structure Equation Modelling (SEM) to achieve the research objective. The results demonstrate that performance was significantly associated with various micro-finance services such as training for managers, training skills, and loan size. In particular, micro-finance programs should be considered by small entrepreneurs, microfinance institutions, and policy makers. Thus, the contribution of this work is the incorporation of micro-finance factors on SMEs performance. Managers of the SMEs will find guidance about which micro-finance factors is the most important for them to be considered in their roles and for improving SMEs performance.
\end{abstract}

2020 by the authors; licensee Growing Science, Canada

\section{Introduction}

The innovation and spirit of firms, generation of wealth in an economy, and availability of job opportunities greatly depend on small-scale firms and businesses. In this manner, competition is fostered among enterprises (Temtime \& Pansiri, 2004; Almansour et al., 2019). According to Gray and Stanworth (1991); Wolff and Pett, (2006), the economic organizations of the country greatly rely on Small and medium-sized enterprises (SMEs). As indicated by Storey et al. (1987), Castrogiovanni (1996), Moutray and Clark (2004), job opportunities are majorly created and provided by small enterprises, and they also have the potential to turn into large corporations and companies in the future. With regards to development and growth, their needs can be better understood by studying SMEs (Norrman, 2008). Due to the contribution of small and medium-sized enterprises to economic and social development, this sector is well known throughout the world. According to Gupta et al. (2013), the SMEs sector has played a vital role in fostering entrepreneurship, exports promotion, output and growth of employment.

In Jordan, government considers that human, social, and economic development greatly depends on the development of Micro Small and Medium Enterprises (MSMEs). The national agenda of 2006-2015 supports MSMEs as a strategy to enhance social security and welfare, as well as stimulate economic development. According to Middle East and North Africa Transition Fund, 2013, the short-term goals of the 2011-2013 Executive Development Plan included "stimulating new start-ups" and "empowering and building the capacity of MSMEs".

In Jordan, various problems such as lack of credit record and lack of collateral is being faced by SMEs which is hindering its growth and development. Therefore, through the developing phase of SME's, there is a risk for financing institutions in investing in them. Funding in such enterprises is avoided by commercial banks due to these risks (Almahrouq \& Muqabla, 2006). In Jordan, almost all the small and medium enterprises face the problem of financing. According to Al-hyari, (2013), the lack of funding and reluctance of banks to finance SME's is evident in the enterprises that require funds in the initial phase of their business, as the small enterprises cannot pledge enough collateral, thus they require loans which are easy to acquire.

* Corresponding author.

E-mail address: n alrawashdeh@asu.edu.jo (N. Alrawashdeh) 
As compared to other developing nations, Jordan lags behind in financing medium and small scaled enterprises; large firms can easily acquire finance as opposed to MSMEs (Nasr \& El Abed, 2013). In North Africa and Middle East nations, there is a fiscal break for financing of small and medium enterprises. Nasr and Rostom (2013) documented that the credit gap for small and medium enterprises is $\$ 547$ million in Jordan.

The capital markets in Jordan are not easily accessible to the SMEs, this is due to the rigid interest rates, and high price of borrowing. Thus, dedicated SMEs departments have been established by a limited number of banks only very few banks have established dedicated SMEs departments, and possess the capability to lend to SMEs, only 11 percent of banks' lending goes to SMEs, compared to 25 percent in emerging markets, also finance sector asking for high collateral equal to $123 \%$ of the loan value (UNDP, 2013).

To solve this problem in Jordan, SMEs focuses on microfinance, and to enhance the microfinance sector in Jordan. In 2011, the national policy framework for microfinance was prepared by Jordan Ministry of Planning and International Cooperation (JMPIC), one of this policy objectives was to "financial service must be made accessible to low-income and poor people in the country" (MOIP, 2011). Micro-loans are considered as a part of the microfinance sector. The micro-loan includes providing lending services to low-income enterprises' owners. While, micro-financing can include lending, saving and other financial services (such as insurance and fund transfer). It is proven that saving has the importance of lending for the poor. That is considered as an indicator for the importance of micro-finance and it is considered a mixture of different financial services (Elia, 2006). This research focused on financial and non-financial services and provide from microfinance institutions on small business performance in Jordan.

\section{Literature review}

Capital structure decisions are widely referred to as debit financing. In small and medium enterprises and in big firms, they all use of either debt or equity or both. Nevertheless, in the situation of small and medium enterprises, this is partially incorrect since information ambiguity is much more intense in SMEs (Berger \& Udell, 1998). Issuing extra equity to satisfy the firm's economic requirements would subsequently help a dilution in control and ownership. In small and medium enterprises, rather than external equity, owner-managers may select to search for debt financing. As indicated by Fatoki (2011) financial capital was discovered to positively and significantly impact SME's performance.

According to Mahmood and Mohd Rosli (2013), the functionality of SMEs is significantly and positively associated with microcredit across all of the microcredit plans under investigation. Anane et al. (2013) claim that recipients of microfinance services and products are better off in conditions of improving outputs, ensuring economic management is efficient, improving the tasks of their small and medium enterprises as compared with those with no microfinance services. Muteru (2013) discovered that microfinance institutions credit amenities that delivers to the females SME business owners had managed to buy extra gear for their firms and use more personnel in order to grow their activities. The amount of loans from microfinance institutions is considerable and favorably associated with functionality of SMEs (Wanambisi \& Bwisa, 2013). The improvement in expenditure of small and micro scale enterprises intermediated by the casual credit market in Nigeria was analyzed by Ojenike and Tayo (2012). The result showed that the dimensions of lending, expertise in lending company had an important and positive effect on growth in investment of small and micro scale enterprises.

A growing number of microfinance groups are trying to develop the human capital of micro business owners to enhance their clients' quality of life and also help their mission of poverty alleviation. According to Shan (2003), recognition by itself cannot impact the SMEs general performance; however, motivational elements greatly contribute to the great overall performance of an enterprise. One of the ways of acquiring such inspiration components could be education, in this regard, through education participants to modify the attitude and the way they perceive their activities. The psychological and social motive could substantially influence development seeking conduct as well as development of the venture (Shan, 2003).

According to Mahmood and Mohd Rosli (2013), entrepreneur specific elements, particularly entrepreneurial management and values are substantial for enhancing firm efficiency. Organizational performance is positively correlated with training policy, as discovered by Ubeda-García et al. (2013). Nevertheless, human along with societal capital was discovered to have positive impact on the performance of the SMEs (Fatoki, 2011). Magableh et al. (2011) discovered that training has a good effect on SMEs' profits, size and revenues, and suggested that authorities and related companies about SMEs in Jordan should focus on supervisors to be able to increase their awareness of the presence as well as advantages of training. Human resources are frequently viewed as a possible supply of sustained competitive advantage, and well trained employees are able to increase the functionality of SMEs (Lorenzet et al., 2006). Jagero et al. (2012) expressed that there was a huge connection between the job training and employee's overall performance. Yahya et al. (2012) discovered that external characteristics and manager enterprises impact the demand for training, and it has a good effect on SMEs efficiency. Employee's overall performance is boosted by training and it also has a positive impact on education which consequently enhances functionality; it is able to boost the amount of organizational and individual competency (Sultana et al., 2012). Dumas and Hanchane (2010) agreed that job training applications boost the competitiveness as well as functionality of the firms. The performance of the company is positively impacted by training, as indicated by Danvila et al. (2009). 
By engaging help from the experts, it is potential for the SMEs to make some improvement on their business viability (Ndubisi, 2008; Audet et al., 2007). Advisory services and training are seen very important for small firm's performance. Kamyabi and Devi (2011) investigated that using advisory services had a positive effect on SME performance in Iran. Robson and Bennett (2000) found a little significant relationship between governments backed providers of business advice and firms' performance. Ahiabor (2013) contended that SMEs should be provided with professional advices at all times by microfinance institutions, as this way lending microfinance institutions will be properly informed whether the requested amount by SMEs is appropriate or not.

The attitudes, abilities of SMEs proprietors as well as how they conduct business activities are enhanced through training, and consequently their ability is improved which affects the performance in a positive way. Together with the good skills; the SMEs owners are able to acquire essential edges while they are under rigid competitive atmosphere. With the help of training, the enterprise owners/managers are able to develop new and better management methods, and develop industrial entities. Microfinance impacts considerably on the degree of efficiency of SMEs operators as well as the provision of non-financial service by microfinance institutions, which improves the functionality of SMEs (Babajide, 2012; Shane, 2003). Fig. 1 represents the research model for this study. Hypothesis represented in Table 1 are as follows.

\section{Table 1}

Hypothesis

\begin{tabular}{ll}
\hline $\mathrm{H}_{1}:$ & Loan size (LS) has a positive effect on small business performance (SBP) \\
$\mathrm{H}_{2}:$ & Use of loan (UL) has a positive effect on small business performance (SBP) \\
$\mathrm{H}_{3}:$ & Training skills (TS) has a positive effect on small business performance (SBP) \\
$\mathrm{H}_{4}:$ & Training for managers (TM) has a positive effect on small business performance (SBP) \\
\hline
\end{tabular}

This paper is intended to test the direct effects of Loan Size (LS), Use of Loan (UL), Training Skills (TS) and Training for Managers (TM) which was provided by microfinance institutions on Small Business Performance (SBP) in Jordan. The hypothesized relationships are demonstrated in Fig. 1 as follows,

Loan Size (LS)

Fig. 1. Framework of microfinance impact on small enterprises performance

\section{Research method}

The empirical strategy incorporates collection of data with the usage of self-questionnaires in a survey. The study was done in central area of Jordan. The reason to select this survey was simply because it is the largest part of SMEs in Jordan. The study concentrated on small businesses. The population of modest enterprises was selected from up to two microfinance institutions in Jordan which are Development and employment fund in Jordan as well as Jordan Micro Credit Company "Tamweelcom". These micro finance institutions have been selected to permit representativeness; addressing the center areas of the nation. The amount of personnel was used to find firms which are SMEs. The confirmatory component analysis (CFA) is held by applied using Structure Equation Modelling (SEM) to allow the built and content validity to be done towards most variables. Nevertheless, 470 questionnaires have been sent out due to the limits related to self-administered questionnaires, 399 non-responded surveys were returned where 91 questionnaires were rejected and the overall questionnaires recognized for analysis were 308 questionnaires.

Likert scale was utilized to elicit responses from the respondents. Financial services supplied from microfinance institution were calculated utilizing the following variables: loan size as well as use of loan, in which non-financial services provided from microfinance institution were measured using the following variables: training techniques as well as education for general management. Small business performance was assessed through fiscal objective strategies.

\section{Empirical Results}

\subsection{Measurement Reliability and Validity}

An analysis of the convergent validity of measures was conducted in this research (Bagozzi \& Yi, 1988). The level to which numerous tries are made to calculate the same idea of agreement is referred to as convergent validity. Convergent validity's evaluation is performed by evaluating the values of Composite Reliability (CR), average variance extracted (AVE) and factor 
loading (Byrne, 2013; Chin, 2010; Hoyle, 1995). Confirmatory Factor Analysis (CFA) analyzed the dependability as well as validity of the measures which were included in the literature. The AMOS graph of the measurement model is depicted in Appendix A. The results are presented in Table 2.

Table 2

Result of CFA for Measurement Model

\begin{tabular}{|c|c|c|c|c|c|}
\hline \multirow[b]{2}{*}{ Construct } & \multirow[b]{2}{*}{ Item } & \multicolumn{3}{|c|}{ Convergent validity } & \multirow[b]{2}{*}{$\begin{array}{l}\text { Internal Reliability } \\
\text { Cronbach Alpha }\end{array}$} \\
\hline & & $\begin{array}{l}\text { Final Factor } \\
\text { Loading }\end{array}$ & $\begin{array}{l}\text { Average Variance } \\
\text { Extracted }(A V E)^{a}\end{array}$ & $\begin{array}{c}\text { Composite Reliability } \\
(\mathbf{C R})^{\mathbf{b}}\end{array}$ & \\
\hline \multirow[t]{9}{*}{ Loan Size (LS) } & $\mathrm{LS}^{\mathrm{d}}$ & 0.717 & \multirow[t]{9}{*}{0.534} & \multirow[t]{9}{*}{0.889} & \multirow[t]{9}{*}{0.892} \\
\hline & LS2 & 0.74 & & & \\
\hline & LS3 & 0.757 & & & \\
\hline & LS4 & 0.763 & & & \\
\hline & LS5 & 0.669 & & & \\
\hline & LS6 & 0.729 & & & \\
\hline & LS7 & 0.693 & & & \\
\hline & LS8 & 0.761 & & & \\
\hline & $\operatorname{ESg}^{c}$ & 0.335 & & & \\
\hline \multirow[t]{4}{*}{ Use of Loan (UL) } & UL1 & 0.791 & \multirow[t]{4}{*}{0.583} & \multirow[t]{4}{*}{0.848} & \multirow[t]{4}{*}{0.848} \\
\hline & UL2 & 0.715 & & & \\
\hline & UL3 & 0.767 & & & \\
\hline & UL4 & 0.78 & & & \\
\hline \multirow[t]{6}{*}{ Training Skills (TS) } & TS1 & 0.776 & \multirow[t]{6}{*}{0.563} & \multirow[t]{6}{*}{0.865} & \multirow[t]{6}{*}{0.866} \\
\hline & TS2 & 0.733 & & & \\
\hline & $\mathrm{TS}^{\mathrm{c}}$ & 0.279 & & & \\
\hline & TS4 & 0.748 & & & \\
\hline & TS5 & 0.765 & & & \\
\hline & TS6 & 0.728 & & & \\
\hline \multirow{6}{*}{$\begin{array}{l}\text { Training for Managers } \\
\text { (TM) }\end{array}$} & TM1 & 0.753 & \multirow[t]{6}{*}{0.554} & \multirow[t]{6}{*}{0.882} & \multirow[t]{6}{*}{0.881} \\
\hline & TM2 & 0.768 & & & \\
\hline & TM3 & 0.729 & & & \\
\hline & TM4 & 0.693 & & & \\
\hline & TM5 & 0.75 & & & \\
\hline & TM6 & 0.77 & & & \\
\hline \multirow{12}{*}{$\begin{array}{l}\text { Small Business } \\
\text { Performance (SBP) }\end{array}$} & SBP1 & 0.865 & \multirow[t]{12}{*}{0.647} & \multirow[t]{12}{*}{0.936} & \multirow[t]{12}{*}{0.936} \\
\hline & SBP2 & 0.728 & & & \\
\hline & SBP $3^{d}$ & 0.811 & & & \\
\hline & SBP4 ${ }^{\mathrm{c}}$ & -0.078 & & & \\
\hline & SBP5 & 0.793 & & & \\
\hline & SBP6 & 0.827 & & & \\
\hline & SBP7 & 0.826 & & & \\
\hline & SBP8 & 0.817 & & & \\
\hline & SBP9 $^{c}$ & -0.032 & & & \\
\hline & SBP10 ${ }^{e}$ & 0.827 & & & \\
\hline & SBP11 & 0.79 & & & \\
\hline & SBP12 & 0.782 & & & \\
\hline \multicolumn{6}{|c|}{$\begin{array}{l}\text { a: Average Variance Extracted }=(\text { summation of the square of the factor loadings }) /\{(\text { summation of the square of the factor loadings })+(\text { summation of the } \\
\text { error variances })\} \text {. } \\
\text { b: Composite reliability }=\text { (square of the summation of the factor loadings }) /\{(\text { square of the summation of the factor loadings })+(\text { square of the summation of } \\
\text { the error variances })\} \text {. } \\
\text { c: } \text { denotes for discarded item due to insufficient factor loading below cut off } 0.5 \text {. } \\
\text { d: denotes for discarded item due to high between-construct error covariance above threshold } 15 \\
\text { e: } \text { denotes for discarded item due to high standardized residual covariance above threshold } 2.58\end{array}$} \\
\hline
\end{tabular}

As demonstrated in Table 2, because of inadequate factor loading under 0.5 LS9, TS3, SBP9 and SBP4 were removed, as suggested by Hair et al. (2006). As stated by Awang (2012), because of considerable between-construct error covariance, SBP3 and LS1 were removed. Lastly, according to Hair et al., (2006), due to increased standardized residual covariance SBP10 was discarded from the model. As recommended by Hair et al. (2006), the threshold of 0.5 was exceeded by factor loading of all the residual items ranging from 0.669 to 0.865 after these items were deleted. According to Hair et al. (2010), the total amount of variance is representative of the extracted average variance in the indicators of a latent construct, were over the recommended value if 0.5 as they ranged between 0.534 and 0.647 . He also stated that degree to which the indicators of a construct exhibit that construct is referred to as composite reliability, was over the recommended value of 0.6 as it ranged between 0.848 and 0.936 . Then, according to Nunnally and Bernstein (1994), the reliability of measures was measured with the help of Cronbach alpha's value. For this situation, the threshold value is 0.7 and Cronbach alpha values for this study raged from 0.848 to 0.936 . According to Fornell and Larcker, (1981), in the next step, a test was conducted for discriminant validity. The constructs correlations and square root can be compared with other constructs in order to test the discriminant validity. Then, as Kline (2005) recommends, 0.85 is the threshold for the correlations between factors in the measurement model and they should not be higher than this value. Table 3 demonstrates the square root of the average variance extracted for each construct is higher than the correlations of that construct with other constructs. In addition to this, the correlations 
were all less than 0.85 , ranged from 0.436 to 0.680 . Acceptable discriminant validity is demonstrated by this result. Conclusively, adequate discriminant, convergent and reliability validity were demonstrated.

Table 3

Discriminant Validity of Constructs

\begin{tabular}{lcrrrr}
\hline Constructs & LS & UL & TS & TM & SBP \\
\hline Loan Size (LS) & $\mathbf{0 . 7 3 1}$ & & & & \\
Use of Loan (UL) & 0.680 & $\mathbf{0 . 7 6 4}$ & & & \\
Training Skills (TS) & 0.436 & 0.563 & $\mathbf{0 . 7 5 0}$ & & \\
Training for Managers (TM) & 0.529 & 0.564 & 0.634 & $\mathbf{0 . 7 4 4}$ & \\
Small Business Performance (SBP) & 0.522 & 0.515 & 0.575 & 0.593 & $\mathbf{0 . 8 0 4}$ \\
\hline
\end{tabular}

Notes. Diagonals represent the average variance extracted, while the other matrix entries represent the square correlations.

\subsection{Structural Model}

As for the structural model, MLE (maximum likelihood estimate) was utilized. The level of Chi-square is 0.000 which is considered significant. Degrees of freedom of 392 with the overall model fit of $\chi 2=494.428$ is presented in appendix B. However, according to Hair et al. (1998), it is suggested to ignore the absolute fit index of minimal difference Chi-square when the sample size is over 200. According to this, it can be estimated that it is a very good absolute. Good fit for the measurement model is also demonstrated by other fit indices. The RMSEA (root mean square error of approximation) was 0.029; 0.981 was the value for IFI (Incremental Fit Index), 0.979 was the value for TLI (Tucker-Lewis index), 0.981 was the value for CFI (comparative fit index), 0.885 was the value for AGFI (adjusted goodness-of-fit), 0.903 was the value for GFI (goodness-of-fit index) and the $\chi 2 / \mathrm{df}$ was 1.261 . Thus, it is safe to conclude that the study developed research model fits the data completely. As indicated by Quaddus and Hofmeyer, (2007), 0.46 was the value for the $\mathrm{R}^{2}$ for SBP (Small Business Performance) above the requirement for the 0.30 cut off value. Appendix B depicts the measurement model AMOS graph. In Appendix C, the results analyzing hypothesized direct effects and the path coefficients can be seen. The structural model's results are presented in detail in Fig. 2.

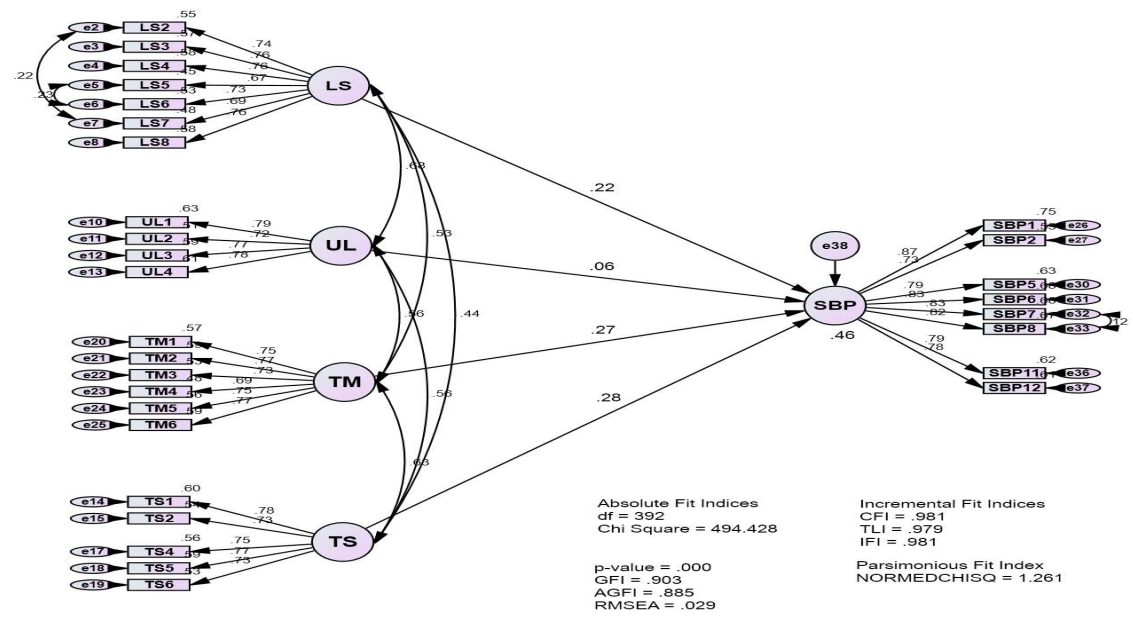

Fig. 2. Structural Model Results

As shown in Fig. 2, there are three paths from Loan Size (LS), Training Skills (TS) and Training for Managers (TM) to Small Business Performance (SBP) which have been found as positive and significant statistically. Thus, hypotheses $\mathrm{H}_{1}, \mathrm{H}_{4}$ and $\mathrm{H}_{3}$ were supported. Alternatively, the substantial impact of usage of Loan (UL) on Small business Performance (SBP) was discovered as statistically minor. Thus, $\mathrm{H}_{2}$ was rejected. The outcomes demonstrated that Training for Managers (TM) was the best significant determinant of Business Performance (SBP) with the conventional coefficient of 0.27.

\section{Discussion and conclusion}

This study aimed at examining the immediate consequences of microfinance services (Loan Size, Use of Loan, Training Skills as well as Training for Managers) on small scale businesses in Jordan. For this purpose, in this study, the two stages of SEM were used. The measurement designs' establishment for the latent constructs in the analysis was provided by the first stage. After uni-dimensionality, validity and reliability were confirmed, the second stage focused at developing research hypotheses by constructing structural models. In order to analyze four hypothesized direct effects, a structural model was developed. For this purpose, path analysis using AMOS was conducted, and in addition to this, the significance of path coefficients for the four hypothesized paths were tested. In the region of Jordan, the research concluded that the firm's performance was signifi- 
cantly enhanced through microcredit programs. The requirements of SMEs cannot be fulfilled by internal resources, specifically finance. Thus, in developing nations such as Jordan, SMEs are assisted through the provision of external resources (support and microcredit) provided by microfinance institutions. In this manner, the performance of the firm is enhanced as the capital gap is bridged by these financial institutions. According to the outcomes, all the direct effect paths were found to be significant and positive, except for direct effect of UL (Use Loan). Thus, the results supported the hypotheses $\mathrm{H}_{1}, \mathrm{H}_{3}$ and $\mathrm{H}_{4}$.

\section{References}

Ahiabor, G. (2013). The impact of microfinance on the development of small scale enterprises in the Ledzorkuku-Krowor municipality in the greater accra region of Ghana. European Journal of Business and Management, 5(7), $165-172$.

Al-Hyari, K. (2013). Identification of barrier factors and potential solutions to SMEs development among Jordanian manufacturing sector. International Journal of Business and Management, 8(24), 132.

Almahrouq, M., Muqabla, E. (2006). Small and medium sized enterprises and their importance, SME Center, Small and medium sized enterprises center. Amman, Jordan

Almansour, B., Almansour, Y., \& Almansour, A. (2019). Small and medium size enterprise: Access the financial and nonfinancial factors. Management Science Letters, 9(5), 687-694.

Anane, G. K., Cobbinah, P. B., \& Manu, J. K. (2013). Sustainability of small and medium scale enterprises in rural Ghana: the role of microfinance institutions. Asian Economic and Financial Review, 3(8), 1003.

Audet, J., Berger-Douce, S., Valenciennes, I. A. E., \& St-Jean, E. (2007). Perceptual barriers preventing Small business owners from using public support services: Evidence from Canada. International Journal of Entrepreneurship, 11, 27-48.

Babajide, A. (2012). Effects of microfinance on micro and small enterprises (SMEs) growth in Nigeria. Asian Economic and Financial Review, 2(3), 463.

Bagozzi, R. P., \& Yi, Y. (1988). On the evaluation of structural equation models. Journal of the Academy of Marketing Science, 16(1), 74-94.

Berger, A., \& F Udell, G. (1998). The economics of small business finance: The roles of private equity and debt markets in the financial growth cycle. Journal of Banking \& Finance, 22(6), 613-673.

Brown, T. A. (2015). Confirmatory factor analysis for applied research. Guilford Publications.

Byrne, B. M. (2013). Structural equation modeling with EQS: Basic concepts, applications, and programming. Routledge.

Castrogiovanni, G. J. (1996). Pre-startup planning and the survival of new small businesses: Theoretical linkages. Journal of Management, 22(6), 801-822.

Chin, W. W. (2010). How to write up and report PLS analyses. In Handbook of Partial Least Squares (pp. 655-690). Springer Berlin Heidelberg.

Danvila del Valle, I., Ángel Sastre Castillo, M., \& Rodríguez-Duarte, A. (2009). The effects of training on performance in service companies: A data panel study. International Journal of Manpower, 30(4), 393-407.

Dumas, A., \& Hanchane, S. (2010). How does job-training increase firm performance? The case of Morocco. International Journal of Manpower, 31(5), 585-602.

Fatoki, O. O. (2011). The impact of human, social and financial capital on the performance of small and medium-sized enterprises (SMEs) in South Africa. Small, 50(R25m), R4m.

Fornell, C., \& Larcker, D. F. (1981). Structural equation models with unobservable variables and measurement error: Algebra and statistics. Journal of Marketing Research, 382-388.

Gray, C., \& Stanworth, J. (1991). Bolton 20 years on: the small firm in the 1990s. University of Illinois at Urbana-Champaign's Academy for Entrepreneurial Leadership Historical Research Reference in Entrepreneurship.

Gupta, P. D., Guha, S., \& Krishnaswami, S. S. (2013). Firm growth and its determinants. Journal of Innovation and Entrepreneurship, 2(1), 15.

Hair, Jr., J. F., Black, W. C., Babin, B. J., Anderson, R. E., \& Tatham, R. L. (2006). Multivariate Data Analysis (6th ed.). Upper Saddle River, NJ: Pearson Prentice Hall.

Hair, Joe F, Ringle, Christian M, \& Sarstedt, Marko. (2011). PLS-SEM: Indeed a silver bullet. The Journal of Marketing Theory and Practice, 19(2), 139-152.

Ho, R. (2006). Handbook of univariate and multivariate data analysis and interpretation with SPSS. CRC Press.

Hoyle, R. H. (Ed.). (1995). Structural equation modeling: Concepts, issues, and applications. Sage Publications.

Jagero, N., Komba, H. V., \& Mlingi, M. N. (2012). Relationship between on the job training and employee's performance in courier companies in Dar es Salaam, Tanzania. International Journal of Humanities and Social Science, 2(22), 114-120.

Kamyabi, Y., \& Devi, S. (2011). Use of professional accountants' advisory services and its impact on SME performance in an emerging economy: A resource-based view. Journal of Management and Sustainability, 1(1), p43.

Krejcie, R. V., \& Morgan, D. W. (1970). Determining sample size for research activities. Educational and Psychological Measurement, 30, 607-610.

Krejcie, R. V., \& Morgan, D. W. (1970). Table for determining sample size from a given population. Educational and Psychological Measurement, 30(3), 607-610.

Lorenzet, S. J., Cook, R. G., \& Ozeki, C. (2006). Improving performance in very small firms through effective assessment and feedback. Education + Training, 48(8/9), 568-583.

Magableh, I. K., Kharabsheh, R., \& Al-Zubi, K. A. (2011). Determinants and impact of training: the case of SMEs in Jordan. International Journal of Economics and Finance, 3(5), p104. 
Mahmood, R., \& Mohd Rosli, M. (2013). Microcredit position in micro and small enterprise performance: the Malaysian case. Management Research Review, 36(5), 436-453.

Moutray, C. M., \& Clark, M. (2004). The Future of Small Business in the US Federal Marketplace. Journal of Public Procurement, 4(3), 450-470.

Muteru, B. (2013). The effect of microfinance institutions on growth of women owned enterprises: A case study of Kenya Women Finance Trust in Kikuyu Township. International Journal of Social Sciences and Entrepreneurship, 1(5), 351371.

Nasr, S., \& Rostom, A. M. (2013). SME contributions to employment, job creation, and growth in the Arab world. Job Creation, and Growth in the Arab World (October 1, 2013).

Ndubisi, N. O. (2008). Small and medium enterprises in the Pacific rim. Arah Pendidikan Sdn Bhd.

Norrman, C. (2008). Entrepreneurship policy: Public support for technology-based ventures (Doctoral dissertation, Linköping University Electronic Press).

Nunnally, J. C. (81). Bernstein, IH (1994). Psychometric theory. New York: McGraw-Hill.

Ojenike, O. J., \& Tayo, A. G. (2012). Informal Credit Markets and the Development of Micro and Small Scale Enterprises in Nigeria. International Journal of Business and Management, 7(23), p1.

Quaddus, M., \& Hofmeyer, G. (2007). An investigation into the factors influencing the adoption of B2B trading exchanges in small businesses. European Journal of Information Systems, 16(3), 202-215.

Robson, P. J., \& Bennett, R. J. (2000). SME growth: the relationship with business advice and external collaboration. Small Business Economics, 15(3), 193-208.

Shane, S. A. (2003). A general theory of entrepreneurship: The individual-opportunity nexus. Edward Elgar Publishing.

Storey, D. J., Keasey, K., Wynarczyk, P., \& Watson, R. (1987). The performance of small firms: profits, jobs and failures. University of Illinois at Urbana-Champaign's Academy for Entrepreneurial Leadership Historical Research Reference in Entrepreneurship.

Sultana, A., Irum, S., Ahmed, K., \& Mehmood, N. (2012). Impact of training on employee performance: A study of telecommunication sector in Pakistan.Interdisciplinary Journal of Contemporary Research in Business, 4(6), 646-661.

Temtime, Z. T., \& Pansiri, J. (2004). Small business critical success/failure factors in developing countries: some evidences from Botswana.

Ubeda-García, M., Marco-Lajara, B., Sabater-Sempere, V., \& García-Lillo, F. (2013). Does training influence organisational performance? Analysis of the Spanish hotel sector. European Journal of Training and Development, 37(4), $380-413$.

United nation development program.(2013, January 1). 2013 Jordan poverty reduction strategy.

Wanambisi, A. N., \& Bwisa, H. M. (2013). Effects of microfinance lending on business performance: A survey of micro and small enterprises in Kitale municipality, Kenya. International Journal of Academic Research in Business and Social Sciences, 3(7), 56.

Wolff, J. A., \& Pett, T. L. (2006). Small-firm performance: Modeling the role of product and process improvements. Journal of Small Business Management, 44(2), 268-284.

Yahya, A. Z., Othman, M. S., \& Shamsuri, A. L. S. (2012). The impact of training on small and medium enterprises (SMEs) performance. Journal of Professional Management, 2(1), 15-25.

\section{Appendix A:}

AMOS graph for measurement (CFA) model

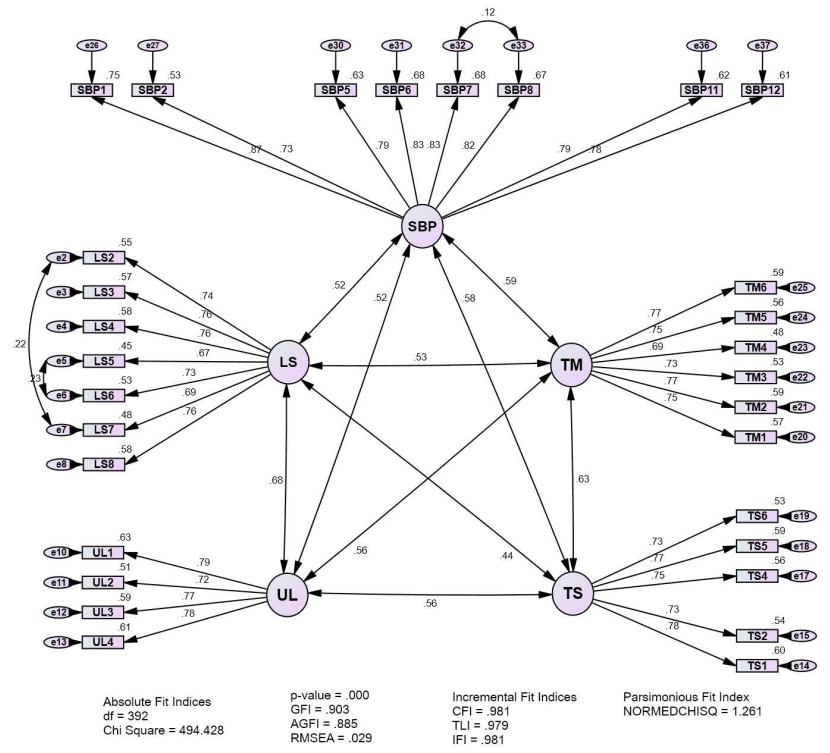


Appendix A:

AMOS graph for structural model

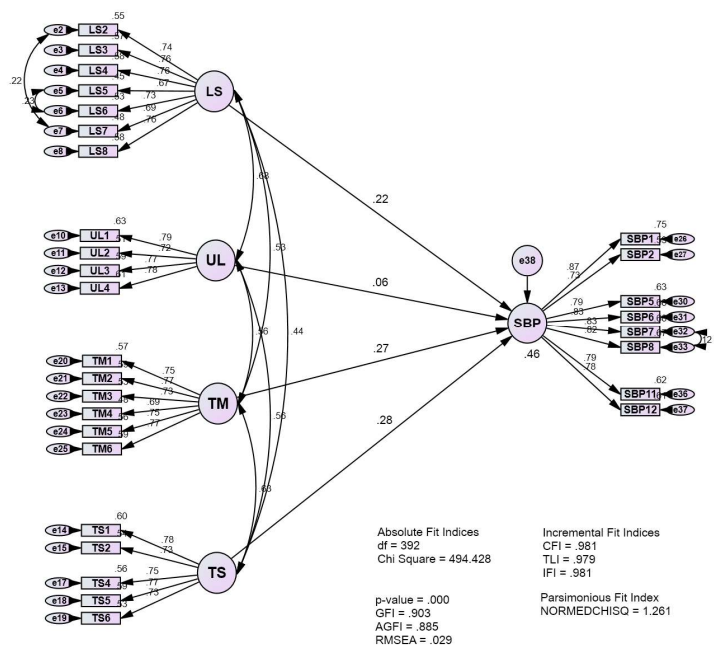

Appendix C:

Regression results

Results of Hypothesized Direct and Indirect Effects in Structural Model

\begin{tabular}{|c|c|c|c|c|c|c|}
\hline \multirow[b]{2}{*}{ Path } & \multicolumn{2}{|c|}{ Unstandardized Estimate } & \multirow{2}{*}{$\begin{array}{c}\text { Standardised Estimate } \\
\text { Beta }\end{array}$} & \multirow[b]{2}{*}{ c.r. } & \multirow[b]{2}{*}{ P-value } & \multirow[b]{2}{*}{ Hypothesis Result } \\
\hline & Estimate & S.E. & & & & \\
\hline $\mathrm{LS} \rightarrow \mathrm{SBP}$ & 0.226 & 0.079 & $0.220^{* *}$ & 2.854 & 0.004 & H1) Supported \\
\hline $\mathrm{UL} \rightarrow \mathrm{SBP}$ & 0.058 & 0.085 & 0.058 & 0.688 & 0.491 & H2) Rejected \\
\hline $\mathrm{TS} \rightarrow \mathrm{SBP}$ & 0.283 & 0.08 & $0.269^{* * *}$ & 3.527 & 0.000 & H3) Supported \\
\hline $\mathrm{TM} \rightarrow \mathrm{SBP}$ & 0.295 & 0.08 & $0.276^{* * *}$ & 3.701 & 0.000 & H4) Supported \\
\hline
\end{tabular}

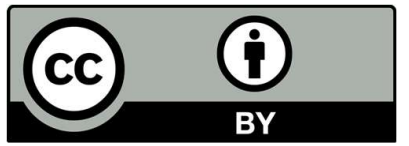

(C) 2020 by the authors; licensee Growing Science, Canada. This is an open access article distributed under the terms and conditions of the Creative Commons Attribution (CC-BY) license (http://creativecommons.org/licenses/by/4.0/). 